\title{
PENGANGGURAN USIA MUDA DI JAWA BARAT (MENGGUNAKAN DATA SAKERNAS)
}

\author{
Adhitya Wardhana ${ }^{1}$ \\ Bayu Kharisma ${ }^{2}$ \\ Yayuf Faridah Ibrahim ${ }^{3}$
}

Fakultas Ekonomi dan Bisnis Universitas Padjadjaran, Jawa Barat, Indonesia ${ }^{1,2,3}$

Email :adhitya.wardhana@unpad.ac.id

\begin{abstract}
The high level of open unemployment at a young age in West Java Province is a crucial issue in the field of employment. This study aims to determine the factors that influence youth unemployment in West Java Province at the micro level. The results of the logistic regression analysis show that age, marital status, status in the household, education and household size have a significant impact on the probability of unemployment at a young age in West Java.
\end{abstract}

Keywords: open unemployment at a young age; logistic regression; age; marital status; status in the household; education and household size.

\begin{abstract}
ABSTRAK
Tingginya tingkat pengangguran terbuka usia muda di Provinsi Jawa Barat merupakan masalah krusial di bidang ketenagakerjaan. Penelitian ini bertujuan untuk mengetahui faktor-faktor yang berpengaruh terhadap pengangguran usia muda di Provinsi Jawa Barat ditingkat mikro. Hasil dari analisis regresi logistik menunjukkan bahwa usia, status perkawinan, status dalam rumah tangga, pendidikan dan ukuran rumah tangga memiliki dampak yang signifikan terhadap probabilitas pengangguran usia muda di Jawa Barat.
\end{abstract}

Kata Kunci: pengangguran terbuka usia muda; regresi logistic; usia; status perkawinan; status dalam rumah tangga; pendidikan dan ukuran rumah tangga.

\section{PENDAHULUAN}

Pertambahan penduduk dan angkatan kerja tidak dibarengi dengan perluasan lapangan kerja. Lapangan kerja yang rendah akan menyebabkan masalah pengangguran. Beberapa negara memiliki penduduk usia muda yang memasuki pasar kerja tapi tidak terserap lapangan kerja. Permasalahan lapangan kerja anak muda menjadi suatu tantangan global. Menurut Corbanese dan Rosas (2015) umumnya anak muda rata-rata memiliki peluang tiga kali lebih besar menjadi pengangguran dibandingkan orang dewasa. Masa transisi antara bersekolah dan bekerja akan terjadi 
di usia muda. Menurut Sziraczki dan Reerink (2004) dalam masa transisi dari sekolah ke bekerja, banyak penduduk muda yang pada usia terlalu muda memasuki dunia kerja dan mereka tidak dipersiapkan untuk menghadapi masa transisi tersebut. Penduduk muda seharusnya mencapai transisi dari sekolah ke pasar kerja dengan melewati masa pencarian pekerjaan atau menganggur yang tidak lama.

Masalah pengangguran kaum muda lebih penting bagi negara-negara berkembang karena tingkat kemiskinan yang tinggi mengharuskan semua orang bekerja untuk memastikan kelangsungan hidup (Msigwa dan Kipesha, 2013). International Labour Organization (ILO) menemukan bahwa mayoritas penduduk usia muda di Indonesia tidak dimanfaatkan dengan baik karena mereka tidak mempunyai akses terhadap pekerjaan yang produktif. Berdasarkan kelompok umurnya, jumlah pengangguran terbuka di Indonesia didominasi oleh pengangguran usia muda. Pada tahun 2017, dari 7,04 juta pengangguran di Indonesia, 72,29 persen atau sebanyak 5,09 juta di antaranya merupakan pengangguran muda usia 15-29 tahun. Dan Provinsi Jawa Barat merupakan kantong pengangguran usia muda di Indonesia, yaitu mencapai 27,37 persen sementara sisanya tersebar di 33 provinsi lainnya. Pengangguran di Provinsi Jawa Barat sendiri juga didominasi oleh usia muda, yaitu 75,73 persen dari total pengangguran di wilayah tersebut.

Adanya isu bonus demografi dimana usia produktif akan mencapai jumlah yang sangat banyak pada beberapa tahun kedepan, maka jumlah pengangguran usia muda yang tinggi ini menjadi permasalahan yang krusial selain ketersediaan lapangan pekerjaan. Dari segi positifnya, orang muda dalam struktur penduduk merupakan bonus demografi, karena mereka adalah tenaga-tenaga potensial produktif yang bisa mendukung pertumbuhan ekonomi. Dari sisi negatifnya, apabila lapangan kerja yang 
produktif tidak tercipta bagi mereka, maka bonus demografi menjadi tidak bermanfaat. Pengangguran usia muda yang tinggi akan menjauhkan dari pertumbuhan ekonomi yang optimal, dan akan meningkatkan resiko ketidakstabilan sosial (Boediono, 2016). Indikator penting yang digunakan untuk mengindikasikan besarnya persentase angkatan kerja yang termasuk dalam pengangguran adalah TPT (Tingkat Pengangguran Terbuka). Pengangguran terbuka tercipta karena penambahan pertumbuhan kesempatan kerja yang lebih rendah dari pada pertumbuhan tenaga kerja, akibat banyaknya tenaga kerja yang tidak memperoleh pekerjaan. Menurut Porket (1995), pengangguran terbuka yang terjadi pada individu dapat diakibatkan oleh "gesekan" yang terjadi dalam proses pencarian pekerjaan, tingginya tingkat upah riil, ketidakcocokan antara penawaran dan permintaan tenaga kerja dalam hal keterampilan dan lokasi, serta adanya inovasi teknologi juga berkontribusi terhadap pengangguran terbuka. Menurut data Sakernas (2017), tingkat pengangguran terbuka Provinsi Jawa Barat pada kelompok usia muda (15-29 tahun) sangat tinggi yaitu mencapai 21,56 persen, jauh di atas TPT kelompok usia dewasa (30 tahun ke atas) yang hanya sebesar 2,80 persen. Hal ini mengindikasikan banyaknya pendatang baru di pasar tenaga kerja menghadapi hambatan yang tidak ringan dalam mencari pekerjaan.

Banyak faktor yang menyebabkan tingginya tingkat pengangguran usia muda, diantaranya adalah kurangnya pendidikan, kurangnya keterampilan, ketidakcocokan struktural, perbedaan antara demografi daerah perkotaan dan pedesaan, kurangnya pengalaman, diskriminasi kebijakan wilayah dalam penyediaan kesempatan kerja, ketidakseimbangan sektoral, dan lain-lain (Qayyum dan Siddiqui, 2007). Penelitian ini bertujuan untuk meneliti faktor-faktor yang menyebabkan pengangguran usia muda di Provinsi Jawa Barat. Analisis faktor-faktor yang menentukan penyebab seseorang 
menjadi pengangguran sangat diperlukan agar informasi yang digunakan dalam pengambilan kebijakan untuk mengurangi pengangguran efektif dan tepat sasaran, khususnya pada pengangguran usia muda yang memiliki proporsi paling tinggi dibanding kelompok usia lainnya.

\section{METODE PENELITIAN}

Penelitian ini menggunakan data cross section yang bersumber dari Survei Angkatan Kerja Nasional (Sakernas) Badan Pusat Statistik, Bulan Agustus tahun 2017 Provinsi Jawa Barat. Survei ini merupakan satu-satunya survei di BPS yang berfokus pada data ketengakerjaan dan dirancang khusus untuk mengumpulkan data yang menggambarkan keadaan umum ketenagakerjaan. Usia muda merujuk pada penelitian Qayyum dan Siddiqui (2008) yang menggunakan batasan usia muda pada rentang 15 - 29 tahun. Dari 16.000 rumah tangga sampel terdapat 12.277 penduduk usia muda. Melalui proses pengkategorian berdasarkan kegiatan utama seminggu yang lalu, diperoleh sampel angkatan kerja usia muda sebanyak 6.685 orang, terdiri dari 1.433 pengangguran dan 5.252 yang bekerja.

Metode analisis yang digunakan dalam penelitian ini adalah metode ekonometri dengan menggunakan regresi logistik. Regresi logistik merupakan model ekonometrika yang bersifat khusus dimana variabel terikatnya berupa data kategorik (biner), dalam hal ini adalah menganggur (1) atau bekerja (0). Model yang digunakan dalam penelitian ini merupakan modifikasi model yang digunakan Qayyum dan Siddiqui (2008) serta Msigwa dan Kipesha (2013), dengan spesifikasi sebagai berikut:

$$
\begin{aligned}
L_{i}=\ln \left(\frac{P_{i}}{1-P_{i}}\right)= & \beta_{0}+\beta_{1} \text { male }_{i}+\beta_{2} \text { age }_{i}+\beta_{3} \text { married }_{i}+\beta_{4} \text { head }_{i}+ \\
& \beta_{5} \text { training }_{i}+\beta_{6} \text { smp }_{i}+\beta_{7} \text { sma }_{i}+\beta_{8} p t_{i}+\beta_{9} \text { rural }_{i}+\varepsilon_{i}
\end{aligned}
$$


dimana $L_{i}$ menunjukkan logaritma natural dari rasio peluang antara $P_{i}$ (peluang menjadi pengangguran usia muda) dan $1-P_{i}$ (peluang menjadi pekerja usia muda), male adalah dummy jenis kelamin (1=laki-laki, 0=perempuan), age adalah umur (tahun), married adalah dummy status perkawinan (1=sudah kawin, $0=$ belum kawin), head adalah dummy status dalam rumah tangga $(1=$ kepala rumah tangga, $0=$ bukan kepala rumah tangga), training adalah dummy keikutsertaan pelatihan $(1=$ pernah mengikuti pelatihan, $0=$ tidak pernah mengikuti pelatihan), smp adalah dummy pendidikan $\mathrm{SMP} /$ sederajat (1= tamat SMP/sederajat, 0=lainnya), sma adalah dummy pendidikan SMA/sederajat (1= tamat SMA/sederajat, 0=lainnya), pt adalah dummy pendidikan perguruan tinggi $(1=$ tamat Perguruan Tinggi, $0=$ lainnya), rural adalah dummy lokasi/wilayah tempat tinggal; $(1=$ perdesaan, $0=$ perkotaan $), \beta$ adalah parameter model, dan $\varepsilon$ adalah error.

Model logit akan ditransformasi ke dalam nilai marginal effect agar dapat diketahui besarnya perubahan probabilitas $\left(\mathrm{P}_{\mathrm{i}}\right)$ yang ditimbulkan oleh setiap perubahan regresornya. Besaran parameter dalam bentuk marginal effect pada model logit adalah sebagai berikut:

$\frac{\partial F\left(x^{\prime} \beta\right)}{\partial x}=\frac{e^{z}}{\left(1+e^{z}\right)^{2}} \beta_{i}$

dimana $\partial F\left(x^{\prime} \beta\right)=\partial y=\partial P$ adalah perubahan nilai $y /$ perubahan peluang, $\partial y$ adalah perubahan nilai $\mathrm{x}, z=\beta_{0}+\beta_{1} X_{i}$, dan $\beta_{i}$ adalah koefisien variabel penjelas i.

\section{HASIL DAN PEMBAHASAN}

Determinasi pengangguran usia muda diidentifikasi dengan menggunakan metode regresi logistik. Tabel di bawah ini menunjukkan hasil regresi logistik penelitian dengan menggunakan Software Stata 14.0. 
Tabel 1.

Hasil Estimasi Regresi Logistik

\begin{tabular}{lcc}
\hline \multicolumn{1}{c}{ Variable } & Coefficient & Marginal Effect \\
& $(1)$ & $(3)$ \\
\hline male & 0,06386 & 0,0096 \\
age*** & $-0,13038$ & $-0,0196$ \\
married*** & $-1,0125$ & $-0,1521$ \\
head $^{* * *}$ & $-1,3914$ & $-0,2090$ \\
training & $-0,0181$ & $-0,0027$ \\
smp** & 0,2512 & 0,0377 \\
sma*** & 0,5315 & 0,0798 \\
pt*** & 0,5056 & 0,0759 \\
hsize* & $-0,0385$ & $-0,0058$ \\
rural & 0,0973 & 0,0146 \\
cons ${ }^{* * *}$ & 1,6178 & \\
& & \\
Number of obs & 6.685 & \\
Log likelihood & $-3.065,5054$ & \\
Pseudo R2 & 0,1173 & \\
Correctly classified & $78,56 \%$ & \\
\hline
\end{tabular}

\section{Sumber: SAKERNAS Agustus 2017, diolah}

Ket : *** : signifikan pada $99 \%$ atau $\alpha=1 \%$

** : signifikan pada $95 \%$ atau $\alpha=5 \%$

* : signifikan pada $90 \%$ atau $\alpha=10 \%$

Dari hasil regresi logistik bahwa jenis kelamin tidak berpengaruh terhadap pengangguran usia muda di Jawa Barat. Menurut penelitian Dagume dan Gyekye (2016) menjelaskan masih terjadi bias gender dalam angkatan kerja usia muda. 
Perarturan mengenai Kesetaraan dalam Ketenagakerjaan di daerah Vhembe, Afrika Selatan sudah diimplementasikan dengan baik tetapi belum menjamin pengangguran usia muda didominasi oleh pria dan wanita. Provinsi Jawa Barat telah menjalankan program peningkatan peran serta dan kesetaraan gender dalam pembangunan. Dinas Tenaga Kerja dan Transmigrasi (2018) sudah mengadakan Program Perlindungan Tenaga Kerja dan Pengembangan Sistem Pengawasan Ketenagakerjaan mengenai kegiatan Peningkatan Kualitas Perlindungan Pekerja Perempuan yang salah satunya adalah pengawasan norma ketenagakerjaan di bidang Norma Penghapusan Diskriminasi Tenaga kerja Perempuan (LKPJ Dinas Tenaga Kerja dan Transmigrasi Provinsi Jawa Barat, 2018).

Berdasarkan hasil regresi logistik yang dilihat dari Marginal effect bahwa pengangguran usia muda di Provinsi Jawa Barat menunjukkan setiap kenaikan 1 tahun umur angkatan kerja muda (rentang 15 - 29 tahun) akan menurunkan peluang menjadi pengangguran muda sebesar 1,96 persen. Dari hasil model logsitik ini menunjukkan bahwa pada awal karir mereka menghadapi lebih banyak kesulitan dalam mencari pekerjaan. Kurangnya pengalaman, keterampilan dan pengetahuan tentang pasar tenaga kerja pada usia muda merupakan salah satu faktor penyebabnya.

Beberapa penelitian menemukan kondisi yang serupa pada penelitian ini seperti penelitian Ahmad dan Azim (2010), Pasay dan Indrayanti (2012), Yuliatin, et al (2016). Penelitian dari Dagume dan Gyekye, 2016) menjelaskan bahwa usia seorang pemuda dapat mempengaruhi status pekerjaan karena fakta bahwa kelayakan kerja berjalan dengan pengalaman. Lulusan baru tanpa pengalaman akan selalu menemukan kesulitan dalam mengakses pekerjaan, karena mereka tidak memiliki pengalaman yang relevan. 
Mereka juga dihadapkan pada persaingan dengan pencari kerja dewasa yang dianggap lebih memiliki pengalaman dan kesiapan dalam pasar kerja.

Hasil dari pengaruh indikator status perkawinan menunjukkan bahwa angkatan kerja muda yang sudah menikah akan menurunkan peluang menjadi pengangguran usia muda bagi sebesar 15,21 persen dibanding yang belum menikah. Hasil ini sejalan dengan temuan oleh Ahmad dan Azim (2010), Pasay dan Indrayanti (2012), Yuliatin, et al (2011), Qayyum dan Siddiqui (2008) dan Nganwa, et al (2015). Individu yang belum menikah relatif belum memiliki beban untuk menafkahi anggota keluarganya sehingga masih berkesempatan memilih pekerjaan yang cocok, disamping itu sebagian besar angkatan kerja usia muda masih tinggal bersama kepala rumah tangganya. Pengaruh pengangguran pada status perkawinan lebih nyata di kalangan laki-laki usia muda dibandingkan perempuan. Hal ini menunjukkan fakta bahwa perempuan yang menikah pada usia muda lebih cenderung berkonsentrasi pada pekerjaan rumah tangga dan membesarkan anak-anak di rumah daripada mencari pekerjaan.

Status dalam rumah tangga merupakan hubungan individu usia muda dengan kepala rumah tangganya, yang dibagi ke dalam dua kategori, yaitu berstatus sebagai kepala rumah tangga dan tidak berstatus kepala rumah tangga (kategori dasar). Berdasarkan hasil dari regresi logistik, bahwa angkatan kerja muda yang menjadi kepala rumah tangga akan mengurangi peluang menjadi pengangguran muda sebesar 20,90 persen dibanding yang tidak menjadi kepala rumah tangga. Kondisi ini sejalan dengan temuan Ahmad dan Azim (2010) serta Yuliatin, et al (2011). Seseorang yang menjadi kepala rumah tangga memiliki tanggung jawab dalam pemenuhan kebutuhan ekonomi anggota keluarganya. Beban dan tanggungan ekonomi tersebut menjadikan 
mereka berupaya lebih keras lagi dan mau menerima pekerjaan apapun daripada menganggur tanpa berpenghasilan.

Variabel pelatihan/kursus/training tidak mempengaruhi terhadap pengangguran usia muda di Jawa Barat. Beberapa penelitian menemukan hal yang sama bahwa tidak ada pengaruhnya antara pelatihan dan pengangguran seperti penelitian yang dilakukan oleh Akhtar dan Shahnaz (2006). Menurut ILO (2007), pelacakan yang belum sistematis, kurang analisa menyeluruh salah satu penyebab variabel tidak mempengaruhi tingkat pengganguran usia muda. Internatioan Labor Organization (2015) menunjukkan kurangnya koordinasi antar lembaga, kurangnya akses bagi pencari kerja, konsentrasi sumber daya di daerah perkotaan yang dominan, serta ketidakcocokan pada jenis keterampilan antara penawaran dan permintaan tenaga kerja yang menimbulkan masalah. Ketidaksesuaian keterampilan menjadi salah satu penyebab pelatihan tidak berdampak terhadap pengangguran usia muda.

Individu yang menyelesaikan pendidikan dasar setingkat SMP/sederajat berpeluang akan meningkatkan peluang menjadi pengangguran usia muda sebesar 3,77 persen. Sementara individu yang menamatkan pendidikan hingga menengah atas (SMA/sederajat) meningkatkan peluang lebih tinggi lagi untuk menjadi pengangguran usia muda sebesar 7,98 persen, sedangkan yang tamat hingga level perguruan tinggi meningkatkan peluang menjadi pengangguran sebesar 7,59 persen.

Hasil ini sesuai dengan penelitian yang dilakukan oleh Msigwa dan Kipesha (2013), Ahmad dan Azim (2010), Akhtar dan Shahnaz (2006), Pasay dan Indrayanti (2012), serta Yuliatin et al (2011). AfDB (2012) menyebutkan bahwa pemuda lulusan universitas, selain memiliki angka tertinggi di pengangguran, mereka juga memiliki standar upah yang paling tinggi. Pendidikan merupakan investasi bagi manusia yang 
akan dirasakan manfaatnya dimasa yang akan datang. Semakin tinggi jenjang pendidikan maka diharapkan pekerjaan yang diperoleh pun lebih baik. Dengan meningkatnya pendidikan, diharapkan mampu pendapatkan pekerjaan dengan upah yang relatif tinggi. Keadaan tersebut menyebabkan tenaga kerja dengan latar belakang pendidikan tinggi lebih memilih menganggur daripada bekerja dengan upah yang kecil dan pekerjaan yang tidak sesuai dengan harapannya (Harfina, 2009).

Menurut laporan ILO (2007), banyak dari kaum muda yang berpendidikan tersebut datang dari keluarga berpenghasilan menengah sampai tinggi. Terlebih lagi mayoritas dari mereka masih tinggal bersama orang tuanya. Oleh karena itu, mereka dapat menjadi pengangguran sembari mencari pekerjaan yang cocok di sektor modern. Selain itu, semakin tinggi pendidikan yang diraih maka opportunity cost yang dikeluarkan pun semakin tinggi sehingga ekspektasi pencapaian kerja dan pendapatan juga semakin tinggi. Bagi mereka yang berpendidikan rendah (tidak mengenyam bangku sekolah dan memiliki pendidikan SD ataupun SMP) mencerminkan bahwa mereka berasal dari keluarga miskin. Oleh karena itu, mereka akhirnya menemukan pekerjaan di sektor informal dengan cepat guna menunjang penghidupan.

Penelitian Dalimunthe (2015) menyatakan bahwa metode dan kurikulum pembelajaran di sekolah sangat akademis, para siswa tidak dikembangkan keterampilan praktis yang relevan dengan pekerjaan dan pengetahuan teknis, serta keterampilan berwirausaha. Tingginya penganggur pada lulusan pendidikan menengah atas dan perguruan tinggi muncul karena ketidakcocokan keterampilan antara kualitas pendidikan dan keterampilan yang diminta oleh pasar tenaga kerja, yang sebagian besar disebabkan oleh rendahnya kualitas pendidikan dan hasil pendidikan yang kurang relevan untuk pasar tenaga kerja (World Bank, 2010). Mereka 
tidak memiliki kompetensi tertentu yang dibutuhkan dunia usaha/industri (Dinas Pendidikan Provinsi Jawa Barat, 2013).

Menurut Ahmad dan Azim (2010), sistem pendidikan yang tidak terkait dengan keterampilan dan pelatihan yang dibutuhkan di pasar tenaga kerja dapat menjadi faktor utama yang berkontribusi terhadap tingginya tingkat pengangguran di kalangan terdidik. Kualitas dan relevansi kurikulum yang didapat dari sekolah masih belum mampu memenuhi kompetensi yang dibutuhkan di pasar kerja, sehingga kemampuan yang didapat dari sekolah tidak serta merta menjadi modal utama bagi pencari kerja untuk bersaing dalam mendapatkan pekerjaan (Ningrum, 2013).

Ukuran rumah tangga menentukan jumlah kebutuhan rumah tangga, ukuran rumah tangga berbanding lurus dengan kebutuhannya. Dalam rumah tangga dengan penghasilan rendah, jumlah tanggungan rumah tangga yang banyak akan cenderung mendorong anggota rumah tangga lainnya ikut bekerja guna membantu pemenuhan kebutuhan ekonomi keluarga. Peningkatan 1 orang anggota rumah tangga akan menurunkan peluang menjadi pengangguran muda sebesar 0,58 persen. Hasil ini sejalan dengan temuan Akhtar dan Shahnaz (2006).

Untuk menangkap efek geografis ataupun pengaruh dari tipologi wilayah pada aktivitas ekonomi angkatan kerja usia muda, maka diteliti lokasi tempat tinggal. Hasilnya menunjukkan bahwa lokasi tempat tinggal individu muda tidak berpengaruh signifikan terhadap peluang seseorang menjadi pengangguran usia muda. kondisi ini juga ditemukan pada penelitian Ahmad dan Azim (2010) yang meneliti pengaruh dari lokasi geografi terhadap peluang individu muda dapat bekerja atau tidak (pengangguran muda) di negara Pakistan. 


\section{SIMPULAN}

Berdasarkan data Survei Angkatan Kerja Nasional (Sakernas) Provinsi Jawa Barat tahun 2017, tingginya pengangguran di Jawa Barat didominasi oleh usia muda. Dengan menggunakan regresi logistik, diteliti faktor-faktor yang berpengaruh terhadap pengangguran usia muda dilihat dari karakteristik demografi, sosial, ekonomi, dan regional. Hasilnya menunjukkan bahwa pendidikan berpengaruh positif terhadap peluang pengangguran usia muda di Jawa Barat tahun 2017. Semakin tinggi pendidikan yang ditamatkan angkatan kerja usia muda maka kecenderungan untuk menjadi pengangguran usia muda pun lebih besar. Variabel modal manusia yang lain, yaitu pelatihan tidak signifikan terhadap pengangguran usia muda di Jawa Barat tahun 2017. Angkatan kerja muda yang pernah mengikuti pelatihan dan tidak pernah mengikuti pelatihan tidak mempengaruhi peluang menjadi pengangguran usia muda.

Umur, status perkawinan, status dalam rumah tangga, dan ukuran rumah tangga signifikan terhadap pengangguran usia muda di Jawa Barat tahun 2017. Peningkatan umur pada angkatan kerja muda akan mengurangi peluang menjadi pengangguran usia muda. Angkatan kerja muda yang sudah menikah berpeluang lebih kecil menjadi pengangguran usia muda dibanding yang belum menikah. Begitu juga dengan mereka yang berstatus sebagai kepala rumah tangga memiliki peluang lebih kecil menjadi pengangguran usia muda. Sementara itu, semakin besar ukuran rumah tangga akan mengurangi peluang menjadi pengangguran usia muda. Sedangkan jenis kelamin dan lokasi tempat tinggal tidak berpengaruh terhadap peluang pengangguran usia muda. 


\section{REFERENSI}

African Development Bank. OECD. UNDP. UNECA (2012). "African Economic Outlook 2012: Promoting Youth Employment". AfDB.

Ahmad, Rizwan dan Parvez Azim. 2010. "Youth Population and The Labour Market of Pakistan: a Micro Level Study." Pakistan Economic and Social Review. Vol 48. No. 2 (Winter 2010). pp 183-208.

Boediono, 2016. "Ekonomi Indonesia dalam Lintasan Sejarah". Bandung: Mizan. BPS, 2017. “Pedoman Pencacah Sakernas Agustus 2017”. Jakarta.

Corbanese, Vallì dan Gianni Rosas. 2015. “Rights@Workfor Youth-Decent Work for Young People". Geneva: ILO.

Dagume, Mbullahei Albert dan Agyapong Gyekye (2016). "Determinants of Youth Unemployment in South Africa: Evidence From The Vhembe District of Limpopo Province." Environmental Economics. Volume 7. Issue 4. 2016.

Dalimunthe, Arfan Aryanto. 2015. "Human Capital Development: Addressing The Missmatch Between Education and Youth Labour Market in Indonesia." Universitas Gadjah Mada.

Dinas Pendidikan Provinsi Jawa Barat. 2013. "Rencana Strategis (Renstra) 2013-2018 Dinas Pendidikan Provinsi Jawa Barat." Bandung.

Dinas Tenaga Kerja dan Transmigrasi. 2018. "Laporan Kinerja Instansi Pemerintah Tahun 2017." Bandung.

Dinas Tenaga Kerja dan Transmigrasi. 2018. "Laporan Keterangan Pertanggungjawaban (LKPJ) Tahun 2017.” Bandung.

ILO. 2015. "Labour and Social Trends in Indonesia 2014-2015 - Strengthening Competitiveness and Productivity Through Decent Work". Jakarta.

ILO. 2015. "Jobs and Skills for Youth: Review of Policies for Youth Employment of Indonesia." Geneva.

ILO . 2017. "Global Employment Trends for Youth 2017”. Geneva.

OECD. 2017. "OECD Skills Outlook 2017 - Skills and Global Value Chains." Paris.

Msigwa, Robert dan Erasmus Fabian Kipesha. 2013. "Determinants of Youth Unemployment in Developing Countries: Evidences from Tanzania". Journal of Economics and Sustainable Development. Vol.4. No.14. 2013. Pages 67-76.

Nganwa, Peace. Deribe Assef dan Paul Mbaka. 2015. "The Nature and Determinants of Urban Youth Unemployment in Ethiopia”. Public Policy and Administration Research. Vol.5. No.3. 2015.

Ningrum, Vanda. 2013. "Tantangan Sosial-Demografi Pengangguran Usia Muda di Indonesia." Jurnal Kependudukan Indonesia Vol 8 No 2 Tahun 2013. Pusat Penelitian Kependudukan - Lembaga Ilmu Pengetahuan Indonesia

Pasay, N. Haidy A. dan Ratna Indrayanti. 2012. "Pengangguran. Lama Mencari Kerja. dan Reservation Wage Tenaga Kerja Terdidik." Jurnal Ekonomi dan Pembangunan Indonesia". Vol. 12 No. 2. Januari 2012: 116-135. Lembaga Demografi FEUI. 
Shinozaki, Takehisa. 2012. "Not by Education Alone: How Young Adults Employment Status Is Determined by Employment Environments and Family Backgrounds". Social Science Japan Journal. Vol. 15. No. 1 (Winter 2012). pp. 31-52.

Wooldridge, Jeffrey M. 2015. "Introductory Econometrics - A Modern Approach (6th edition)". USA: Cengage Learning.

World Bank. 2010. "Education, Training, and Labor Market Outcomes for Youth in Indonesia." Report No. 54170-ID. Jakarta: World Bank.

Yuliatin, Tun Huseno dan Febriani. 2011. "Pengaruh Karakteristik Kependudukan Terhadap Pengangguran di Sumatera Barat." Jurnal Manajemen dan Kewirausahaan. Volume 2. Nomor 2. Mei 2011. 